\section{Oldest US college looks to future}

Cambridge, Massachusetts

"By Universe, I mean the universe in which Harvard is located." Thus did Professor George B. Field, professor of astronomy at Harvard University, ironically echo the mood of three days of celebrations of the 350th anniversary of the oldest university in the United States, some thousands of whose 230,000 living alumni had come back hoping to be told that Harvard remains central to everything.

The celebrations have been at once a spellbinding demonstration of the richness of Harvard's scholarship and a proof that, whatever the intent, sentimental banality is unavoidable on these occasions. The hard core of the programme has been a series of a hundred or so symposia in which academics have given thumbnail accounts of their work, mostly both witty and articulate. The schmaltz is typified by the closing ceremony at which Mr Walter Cronkite, the legendary TV anchorman with no previous Harvard connections, read a script explaining that after sustaining Puritanism for more than a century and then driving off the British, Harvard alumni went on to banish the great depression, to win the Second World War, to solve the Cuban missile crisis and to launch the drive into worlds beyond our World. The alumni, having come to hear just this, went off into the night humming "Fair Harvard, ...".

The speakers' rostrum has as often been occupied by the Great and the Good, bearing greetings from elsewhere, as by the presidents of the network of alumni associations (in which, as one put it, membership entails "no dues, but from which there is no escape"). President Ronald Reagan was nevertheless conspicuous by his absence; he had been invited, as is traditional, but declined only after Harvard had decided to break with tradition and not to award its distinguished speakers honorary degrees.

The Prince of Wales, heir to the British throne and pinch-hitting for his father, who is the Chancellor of the University of Cambridge and Harvard's traditional guest on these occasions, made a nicely judged plea that "we have not only to teach men how to make things, but also to produce people who have complete moral control over the things they make". And, to come to grips with the "dark side of man's psyche", he urged that more attention should be paid to the "natural science of psychology", a cause to which the British royal family has hitherto paid little attention.

Mr George Schultz, the US Secretary of State, arguing that it takes a free country to develop better means of communication and thus an information revolution, attacked protectionism (and the US Coning attempts to force the pace of change in South Africa) and isolationism (particularly the Congress's attack on the State Department's own budget). Mr Shultz's rehearsal of the US administration's present international stance was spiced with a protest at the arrest in Moscow on a charge of espionage of Mr Nicholas Daniloff, a Harvard graduate of 1956.

Mr Caspar Weinberger, US Secretary of Defense, made a similar protest at a symposium on the Kennedy School of Government's project under the title "avoiding nuclear war", but then went on to disappoint an expert audience because his restatement of the administration's view that the Strategic Defense Initiative is the "better way" than mutually assured deterrence lacked the subtlety expected on an academic occasion. But Mr Weinberger, fair play, was having to deal with notes and whispers about the hijacking of

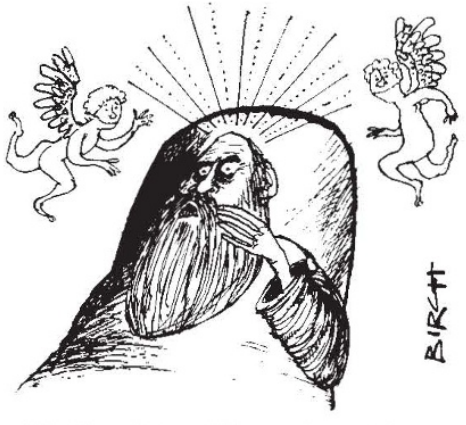

$$
\text { Me? Yale, I'm afraid... }
$$

the Pan-American aircraft in Pakistan. As at Sheik Yamani's eariier breathtaking plea for stable oil prices, there were armed Boston policemen (and men with bulging jackets and pentagonal badges) standing around the lecture room.

The symposia have nevertheless been extraordinarily stimulating. Field's symposium had Professor Steven Weinberg confessing himself a convert to superstring theories of elementary particles and Professor Irwin Shapiro saying that it is only a matter of time before very long baseline interferometry yields absolute distances to at least one quasar with an interposing gravitational lens. The parallel computer people showed that their field is full of promise yet still in its infancy. Professor Richard Wilson's moderate defence of nuclear power excited a spate of moderate questions. Molecular biology, of which Harvard has cause to be proud, was curiously muted, with Professor Walter Gilbert's account of what things are possible unsupported by the medical school, which has had almost nothing to say for itself.

Much talk has been about the future, gress for harbouring it), moralism (mean- that of the world and, inevitably, of Harvard. If money is all that matters, Harvard must be among the safest of institutions. By the end of June last year, its endowment funds had topped $\$ 3,000$ million, and contributed $\$ 110$ million a year of the total operating costs of $\$ 650$ million a year. University administrators elsewhere are especially envious of the way the university finances new projects by issuing tax-exempt bonds and of the deliberate way in which maintenance is planned by the yardstick of the replacement cost of buildings. The average professor's salary in the Faculty of Arts and Sciences now amounts to $\$ 66,000$, the highest in the United States (and nearly twice that of people without tenure). The endowment fund explains why 85 per cent of undergraduates (among whom American-Asians now amount to 9 per cent) receive some form of scholarship aid, which takes the edge off some academics' shame that the cost of a Harvard education should now be $\$ 17,000$ a year.

The cost is one threat to the future and to open access. Dr Derek Bok, president of Harvard for the past 17 years and a lowkey orator with a reputation for compromise, identified another last week: "as people read of the monetary value of a Harvard diploma, the swelling size of the endowment and the fabled influence of the old-boy network, fascination and respect easily turn to envy and resentment".

But Bok's main message was embedded in a plea for functional independence from government and freedom from pressures to help solve social problems in ways that compromise the proper functions of the university (which was generally understood to refer to the way anti-apartheid activists prevented 350 university guests from dining on Thursday evening). It is the danger that the growth of extracurricular activities by professors will create a generation of academics seeking "to combine the freedom and security of a tenured academic post with the income and visibility traditionally reserved for people who take greater risks".

John Maddox

\section{Medals for twenty}

INSTEAD of the usual honorary degrees, Harvard this year awarded university medals to twenty people including Professor Margaret Kivelson (Earth and Space Sciences, University of California, Los Angeles); Dr Adetokundo O. Lucas (now with the Carnegie Corporation, but director of the WHO programme for research training in tropical diseases until earlier this year); Dr Raymond J. Nagle (now retired as professor of Dental Medicine at Harvard); Dr Edward Purcell (retired professor of physics at Harvard) and Dr Carl W. Walter (professor of surgery until his retirement in the early 1960 s). 